\title{
Implementasi Supervisi Akademik untuk Meningkatkan Kinerja Guru
}

\section{Gusti Ayu Kusumawati*}

UPT Kecamatan Blahbatuh Gianyar

\section{A R T I C L E I N F O}

Article history:

Received 12 February 2020

Received in revised form

18 March 2020

Accepted 30 April 2020

Available online 27 May 2020

\section{Kata Kunci:}

Kinerja Guru, Supervisi

Akademik

Keywords:

Teacher Performance,

Academic Supervision
A B S T R A K

Tujuan dari penelitian ini adalah untuk mengetahui peningkatan kinerja guru SD di Gugus 3 Kecamatan Blahbatuh Kabupaten Gianyar Semester I Tahun Pelajaran 2019/2020 setelah diimplementasikannya supervisi akademik. Penelitian ini adalah penelitian tindakan sekolah. Subjek penelitian adalah guru SD di Gugus 3 Kecamatan Blahbatuh Kabupaten Gianyar yang berjumlah 58 orang guru. Data kinerja guru pada penelitian ini dikumpulkan menggunakan kuesioner. Teknik analisis data menggunakan analisis deskriptif. Indikator keberhasilan penelitian ini adalah: apabila rata-rata kinerja guru minimal pada kategori Tinggi, dan ketuntasan klasikal sebesar $90 \%$. Berdasarkan penelitian yang telah dilakukan, disimpulkan bahwa implementasi supervisi akademik secara efektif dapat meningkatkan kinerja guru SD di gugus 3 Kecamatan Blahbatuh Kabupaten Gianyar Semester I tahun pelajaran 2019/2020. Hal ini ditunjukkan dari rerata kinerja guru sebelum penelitian sebesar 120,64 berada pada kategori sedang, meningkat pada siklus I menjadi 141,98 berada pada kategori tinggi dan meningkat lagi pada siklus II menjadi 174,57 berada pada kategori sangat tinggi.

\section{A B S T R A C T}

The purpose of this study was to determine the improvement in the performance of elementary school teachers in Cluster 3 of Blahbatuh District, Gianyar Regency Semester I in 2019/2020 Academic Year after the implementation of academic supervision. This research is a school action research. Subjects were elementary school teachers in Cluster 3, Blahbatuh District, Gianyar Regency with a total of 58 teachers. Teacher performance data in this study were collected using a questionnaire. Data analysis techniques using descriptive analysis. Indicators of success of this study are: if the average teacher performance is at least in the High category, and classical completeness is $90 \%$. Based on research that has been done, it is concluded that the implementation of academic supervision can effectively improve the performance of elementary school teachers in cluster 3 of Blahbatuh District, Gianyar Regency Semester I in the academic year 2019/2020. This is indicated from the average teacher performance before the study amounting to 120.64 in the medium category, increasing in the first cycle to 141.98 in the high category and increasing again in the second cycle to 174.57 in the very high category. 


\section{Pendahuluan}

Pendidikan berfungsi untuk mendidik siswa menuju perubahan diri ke arah yang lebih baik, memberikan pengetahuan yang luas dan keterampilan yang diperlukan untuk hidup dan berkompetisi dalam dunia yang kompetitif. Hal ini berarti bahwa proses pendidikan yang dilakukan pada saat ini bukan semata-mata untuk hari ini, melaikan untuk masa depan. Undang-undang No. 20 tahun 2003 tentang Sistem Pendidikan Nasional pasal 1 ayat 1 pendidikan 2 adalah usaha sadar dan terencana untuk mewujudkan suasana belajar dan proses pembelajaran agar siawa secara aktif mengembangkan potensi dirinya untuk memiliki kekuatan spiritual keagamaan, pengendalian diri, kepribadian, kecerdasan, akhlak mulia, serta keterampilan yang diperlukan dirinya, masyarakat, bangsa dan Negara. Menurut Omeri (2015) Pendidikan bukanlah proses yang diorganisasi secara teratur, terencana, dan menggunakan metode-metode yang dipelajari serta berdasarkan aturan-aturan yang telah disepakati mekanisme penyelenggaraan oleh suatu komunitas suatu masyarakat (Negara), melainkan lebih merupakan bagian dari kehidupan yang memang telah berjalan sejak manusia itu ada.Pendidikan bisa dianggap sebagai proses yang terjadi secara sengaja, direncanakan, didesain, dan diorganisasi berdasarkan aturan yang berlaku. Menurut Munirah (2015) sistem pendidikan di Indonesia dewasa ini tampak ada kesenjangan antara kenginan dan realita. Secara makro dapat dilihat dalam aspek pengelolaan, peran pemerintah dan masyarakat, kurikulum atau materi ajar, pendekatan dan metodologi pembelajaran, sumber daya manusia, lingkungan kampus atau sekolah, dana, dan akreditasi. Kesenjangan dalam sistem pendidikan tersebut disebabkan karena faktor politik, ekonomi, sosial-budaya dan sebagainya yang selalu berubah sesuai dengan perubahan dan perkembangan zaman. Menurut Afrianto (2011) Kebutuhan pendidikan merupakan salah satu bagian terpenting dari kehidupan manusia, dengan pendidikan yang lebih tinggi diharapkan akan manghasilkan manusia-manusia yang lebih berkualitas.

Upaya meningkatkan mutu pendidikan diawali dari perbaikan kualitas ditingkat dasar. Terutama perbaikan pada proses pembelajaran di sekolah dasar, sebab pembelajaran di sekolah dasar merupakan tahap awal untuk menuju ketingkat selanjutnya. Ibarat bangunan, apabila pondasinya kokoh maka bangunannya akan kokoh. Pendidikan ialah suatu proses pembelajaran untuk mengembangkan potensi peserta didik agar dapat menyesuaikan diri terhadap lingkungannya.

Pada jenjang pendidikan dasar, kunci utamanya adalah Guru. Hal itu dikarenakan guru secara langsung berhadapan dengan siswa dalam proses pembelajaran. Guru secara fungsional tugas utamanya adalah memberikan layanan teknis kependidikan kepada siswa.

Untuk mendorong upaya profesinalisme guru, faktor yang tidak boleh dikesampingkan adalah pengawasan atau supervisi. Supervisi di sekolah terhadap kinerja guru dalam proses pembelajaran dilakukan oleh pengawas dan pengawas sesuai Peraturan Menteri Pendidikan Nasional Nomor 13 Tahun 2007 tentang Standar pengawas/Madrasah menegaskan bahwa seorang pengawas/madrasah harus memiliki lima dimensi kompetensi minimal yaitu: kompetensi kepribadian, manajerial, kewirausahaan, supervisi, dan sosial juga pengawas harus memiliki kompetensi guru yaitu: kompetensi paedagogik, kepribadian, sosial, dan profesional. Salah satu indikator kompetensi profesional adalah kompetensi pengembangan diri (profesi) yaitu, sebagai pemimpin institusi, manajer sekaligus juga supervisor.

Realita kinerja guru di SD Gugus 3 Kecamatan Blahbatuh Kabupaten Gianyar Semester I Tahun Pelajaran 2019/2020 adalah terlihat adanya kinerja guru yang masih belum optimal dalam mendidik para siswanya, sehingga para siswa cenderung bersifat konstan dalam menyerap dan mempraktekkan ilmu pengetahuan yang diperoleh di sekolah untuk diterapkan dalam lingkungan masyarakat. Sebagai dampak yang lebih luas lagi, yaitu para siswa kurang memahami ilmu pengetahuan yang sedang berkembang dalam kehidupan bermasyarakat. Adapun fenomena diatas terjadi disebabkan oleh faktor-faktor sebagai berikut: redahnya kinerja guru dalam mendidik dan mentransformasikan berbagai ilmu pengetahuan pada siswanya, belum efektifnya supervisi, dan kurangnya kemampuan guru dalam menggunakan IT sehingga membuat guru kurang update informasi terkini.

Untuk mengatasi permasalahan di atas, dapat dilakukan dengan menerapkan supervisi akademik. Supervisi akademik merupakan upaya membantu guru-guru mengembangkan kemampuannya mencapai tujuan pembelajaran. Dengan demikian, berarti esensi supervisi akademik itu sama sekali bukan menilai kinerja guru dalam mengelola proses pembelajaran, melainkan membantu guru mengembangkan kemampuan profesionalismenya.

Berdasarkan pemaparan di atas, maka pada penelitian ini akan mengambil judul tentang Implementasi Supervisi Akademik Untuk Meningkatkan Kinerja Guru SD di Gugus 3 Kecamatan Blahbatuh Kabupaten Gianyar Semester I Tahun Pelajaran 2019/2020.

Tujuan dari penelitian ini adalah untuk mengetahui peningkatan kinerja guru SD di Gugus 3 Kecamatan Blahbatuh Kabupaten Gianyar Semester I Tahun Pelajaran 2019/2020 setelah mengikuti supervisi akademik. 


\section{Metode}

Penelitian ini dilaksanakan di Gugus 3 Kecamatan Blahbatuh Kabupaten Gianyar Semester I Tahun Pelajaran 2019/2020. Penelitian ini dilaksanakan dari bulan Juli sampai Oktober 2019. Dalam penelitian ini yang menjadi subjek penelitian adalah guru SD di gugus 3 Kecamatan Blahbatuh Kabupaten Gianyar Semester I tahun pelajaran 2019/2020 sebanyak 58 orang guru. Sedangkan objek dari penelitian ini adalah kinerja guru dengan mengikuti supervisi akademik.

Jenis penelitian ini adalah penelitian tindakan sekolah (PTS). Penelitian tindakan sekolah merupakan suatu penelitian yang bertujuan untuk memperbaiki kegiatan-kegiatan yang dilaksanakan di sekolah, sehingga kualitas sekolah dapat ditingkatkan. Penelitian tindakan sekolah (PTS) ini ada empat tahapan pada satu siklus penelitian. Keempat tahapan tersebut terdiri dari: planing, action, observation/evaluation, dan reflection. Pelaksanaan penelitian ini dilakukan beberapa siklus, dan setiap siklus tersebut dapat digambarkan dalam model seperti gambar sebagai berikut.

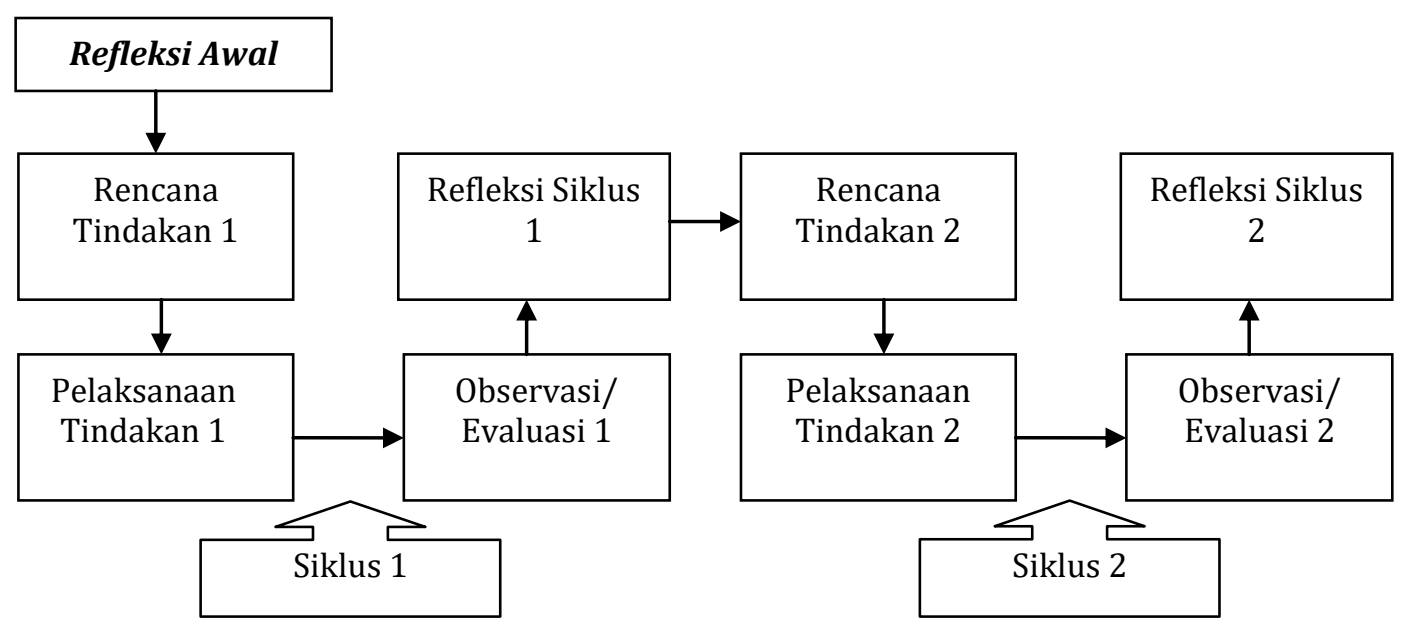

(Agung, 2010)

Gambar. 1. Model Penelitian Tindakan Sekolah Dua Siklus

Dalam penelitian ini digunakan metode pengumpulan data yaitu metode kuesioner. Metode kuesioner merupakan salah satu dari berbagai metode dalam pengumpulan data. Menurut Agung (2010:58), metode kuesioner adalah suatu cara memperoleh data dengan jalan memberikan kuesioner kepada responden, dan responden mengisi kuesioner tersebut dengan kenyataan atau realita yang ada. Dalam penelitian ini, metode kuesioner digunakan untuk mengumpulkan data tentang Kinerja guru. Kuesioner yang dibuat menggunakan skala likert 1-5, sehingga data yang diperoleh berupa skor.

Setelah data dalam penelitian ini terkumpul selanjutnya dilakukan analisis data. Ada dua jenis metode analisis statistik yaitu metode analisis statistik deskriptif dan metode analisis statistik inferensial. Dalam penerapan metode analisis statistik deskriptif ini, data yang diperoleh dari hasil penelitian dianalisis dan disajikan ke dalam: a) menghitung angka rata-rata (Mean), b) menghitung median, c) menghitung modus. Mean, median modus dihitung dengan bantuan Microsoft excel. berikut.

Selanjutnya, rata-rata persen dibandingkan dengan Pedoman Konversi Skala Lima sebagai

Tabel 1. Pedoman Konversi Skala Lima

\begin{tabular}{ccc}
\hline NO & SKALA & KLASIFIKASI \\
\hline 1. & $\mathrm{X} \geq \mathrm{Mi}+1,5 \mathrm{SDi}$ & sangat tinggi \\
2. & $\mathrm{Mi}+1,5 \mathrm{SDi}>\mathrm{X} \geq \mathrm{Mi}+0,5 \mathrm{SDi}$ & tinggi \\
3. & $\mathrm{Mi}+0,5 \mathrm{SDi}>\mathrm{X} \geq \mathrm{Mi}-0,5 \mathrm{SDi}$ & sedang \\
4. & $\mathrm{Mi}-0,5 \mathrm{SDi}>\mathrm{X} \geq \mathrm{Mi}-1,5 \mathrm{SDi}$ & rendah \\
5. & $\mathrm{X}<\mathrm{Mi}-1,5 \mathrm{SDi}$ & sangat rendah \\
\hline
\end{tabular}


Keterangan :

$\mathrm{Mi}=1 / 2($ skor maksimum + skor minimum)

$\mathrm{SDi}=1 / 6$ (skor maksimum - skor minimum)

Indikator keberhasilan penelitian ini, berpedoman pada kriteria berikut. Tingkat keberhasilan dalam penelitian ini adalah apabila rata-rata kinerja guru minimal pada kategori Tinggi, dan ketuntasan klasikal sebesar $90 \%$.

\section{Hasil dan Pembahasan}

Dalam dunia pendidikan kinerja guru merupakan hal yang sangat penting dan perlu perhatian khusus. Menurut Payman J. Simanjutak (Susanto, 2016:69) kinerja adalah tingkat pencapaian hasil atas pelaksanaan tugas tertentu dalam rangka pencapaian tujuan organisasi. Senada dengan Prawirosentono (Susanto, 2016:69) mengartikan kinerja sebagai hasil kerja yang dapat dicapai oleh seseorang kelompok orang dalam suatu orgnisasi, sesuai dengan wewenang dan tanggung jawab masing-masing dalam rangka upaya mencapai tujuan organisasi bersangkutan secara legal, tidak melanggar hukum dan sesuai dengan moral dan etika.

Menurut Stoner (dalam Uha, 2013:213) kinerja adalah fungsi dari motivasi, kecakapan, dan prestasi peranannya. Bernardi dan Russel (dalam Uha, 2013:213) mendifinisikan kinerja sebagai pencatatan hasil-hasil yang diperoleh dari fungsi pekerjaan atau kegiatan tertentu selama kurun waktu tertentu. Menurut Handoko kinerja sebagai proses dimana organisasi mengevaluasi atau menilai prestasi kerja karyawan. Pendapat lain dikemukakan oleh Gibson (dalam Uha, 2013:213) bahwa kinerja seseorang ditentukan oleh kemampuan dan motivasi untuk melaksanakan pekerjaannya. Selanjutnya dikatakan pelaksanaan pekerjaan ditentukan oleh interaksi kemampuan dan motivasi.

Pengukuran kinerja digunakan sebagai dasar untuk menilai keberhasilan dan kegagalan pelaksanaan kegiatan sesuai dengan sasaran dan tujuan yang telah ditetapkan dalam rangka mewujudkan visi dan misi seklah. Pengukuran dimaksud merupakan hasil dari suatu penilaian yang sistematik dan didasarkan pada kelompok indikator kinerja kegiatan yang berupa indikator-indikator masukan, keluaran, hasil manfaat, dan dampak sebagaimana diuraikan pada bab sebelumnya. Penilaian tersebut tidak terlepas dari proses yang merupakan kegiatan mengolah masukan menjadi keluaran atau penilaian dalam proses penyusunan kebijakan/program/kegiatan yang dianggap penting dan berpengaruh terhadap pencapaian sasaran dan tujuan.

Upaya yang dapat dilakukan dalam meningkatkan kinerja guru adalah dengan mengimplementasikan supervisi akademik. Tujuan dilaksanakannya supervisi akademik adalah membantu guru mengembangkan kemampuannya mencapai tujuan pembelajaran melalui pembinaan dan peningkatan profesi mengajar kepada siswanya di kelas. Melalui supervisi akademik diharapkan kualitas akademik para guru semakin meningkat (Neagley, 1980). Pengembangan kemampuan dalam konteks ini janganlah ditafsirkan secara sempit, semata-mata ditekankan pada peningkatan pengetahuan dan keterampilan mengajar guru, melainkan juga meningkatkan komitmen (Comitmen) atau kemauan (Willingness) atau motivasi (Motivation) guru, sebab dengan meningkatkan kemampuan dan kompetensi profesional guru, kualitas pembelajaran akan meningkat.

Menurut Alfonso, Firth dan Neville (1981) supervisi akademik yang baik adalah supervisi yang mampu berfungsi mencapai multi tujuan tersebut diatas. Tidak ada keberhasilan bagi supervisi akademik jika hanya memperhatikan salah satu tujuan tertentu dengan mengesampingkan tujuan lainya. Hanya dengan merefleksi ketiga tujuan inilah supervisi akademik akan berfungsi mengubah perilaku mengajar guru. Pada gilirannya nanti perubahan perilaku guru kearah yang lebih baik.

Berdasarkan implementasi supervisi akademik yang telah dilakukan di SD Gugus 3 Kecamatan Blahbatuh Kabupaten Gianyar Semester I Tahun Pelajaran 2019/2020, pada siklus I didapatkan rerata kinerja guru adalah 141,175 dan berada pada kategori tinggi. Persentase ketuntasan klasikalnya adalah $65,52 \%$. Hal tersebut dikarenakan 20 orang guru mendapatkan skor yang berada pada kategori sedang. Kendala yang dihadapi pada siklus I adalah guru masih belum mampu menguasai teknologi informasi dan komunikasi dengan baik, dan guru belum mampu mengembangkan materi pembelajaran dengan menggunakan inovasi-inovasi yang baru, sehingga pembelajaran masih terkesan monoton.

Berdasarkan pemaparan di atas, kategori kinerja guru berada pada kategori tinggi dan ketuntasan guru tidak mencapai 90\% sehingga belum mencapai kategori dan ketuntasan yang ditetapkan oleh peneliti, yakni kategori kinerja guru berada pada kategori minimal tinggi dan dan kentutasan klasikal 90\%. Sehingga dapat disimpulkan bahwa siklus I belum berhasil dan harus diadakan siklus II dengan memperhatikan kendala-kendala yang dihadapi siklus I. 
Berdasarkan pemaparan di atas, pada siklus II rerata kinerja guru adalah 174,57 dan berada pada kategori sangat tinggi. Persentase ketuntasan klasikalnya adalah 96,55\%. Hal ini menunjukkan bahwa kendala-kendala yang dihadapi pada siklus I sudah dapat diatasi pada siklus II. Maka dari itu kriteria ketuntasan minimal baik dan ketuntasan klasikal 90\% sudah terpenuhi sehingga penelitian pada siklus II dinyatakan berhasil dan siklus dihentikan.

Tabel 2. Rangkuman Data Hasil Penelitian

\begin{tabular}{lccc}
\hline \multicolumn{1}{c}{ No } & Pra Siklus & Siklus I & Siklus II \\
\hline Rata-rata & 120,64 & 141,98 & 174,57 \\
Kategori & Sedang & Tinggi & Sangat Tinggi \\
Ketuntasan & $10,35 \%$ & $65,52 \%$ & $96,55 \%$ \\
\hline
\end{tabular}

Hasil di atas, dapat digambarkan pada grafik berikut ini.

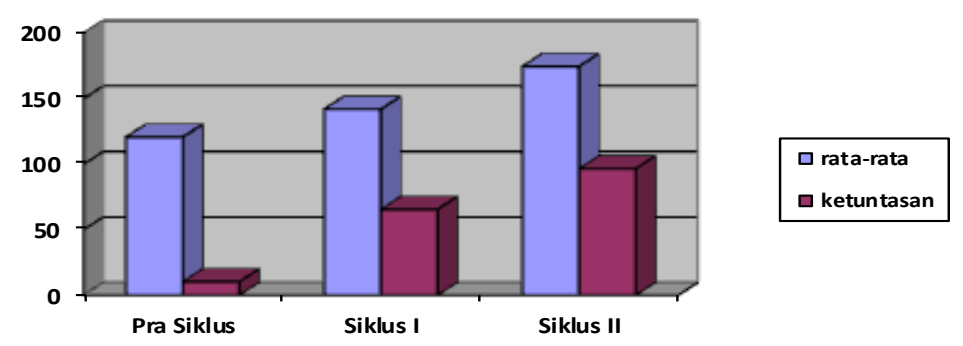

Gambar 2. Rangkuman Hasil Penelitian

Hasil penelitian ini sejalan dengan hasil penelitian yang dilakukan oleh Leniwati dan Yasir Arafat (2017) dengan judul Implementasi Supervisi Akademik Kepala Sekolah Untuk Meningkatkan Kinerja Guru. Pada penelitiannya disimpulkan bahwa: Dalam implementasi supervisi akademik di SMAN 1 Sembawa dilakukan melalui 3 (tiga) tahap, yaitu perencanaan, pelaksanaan, dan evaluasi atau tindak lanjut dari supervisi tersebut. Dalam perencanaan, kepala sekolah menerbitkan surat keputusan (SK) yang dilampiri jadwal pelaksanaan supervisi. Dalam pelaksanaannya, kegiatan supervisi dilaksanakan dengan cara biasa (di luar kelas) dan klinis ( dalam kelas). Guru - guru SMAN 1 Sembawa merespon positif supervisi akademik oleh kepala sekolah karena kegiatan supervisi sangatlah penting dilakukan untuk mengubah kinerja guru menjadi lebih baik.

Selvia (2015) dengan judul Implementasi Supervisi Akademik Kepala Sekolah Dalam Peningkatan Profesionalisme Guru. .Hasil penelitian ini menunjukkan bahwa implementasi supervisi akademik kepala sekolah dalam meningkatkan profesionalisme guru sudah terlaksanan dengan baik, sehingga profesionalisme guru dapat ditingkatkan.

\section{Simpulan dan Saran}

Berdasarkan penelitian yang telah dilakukan dapat disimpulkan bahwa: implementasi supervisi akademik secara efektif dapat meningkatkan kinerja guru SD di gugus 3 Kecamatan Blahbatuh Kabupaten Gianyar Semester I tahun pelajaran 2019/2020. Hal ini ditunjukkan dari rerata kinerja guru sebelum penelitian sebesar 120,64 berada pada kategori sedang, meningkat pada siklus I menjadi 141,98 berada pada kategori tinggi dan meningkat lagi pada siklus II menjadi 174,57 berada pada kategori sangat tinggi.

Dari simpulan di atas, dapat disarankan hal-hal sebagai berikut: 1) Guru hendaknya selalu berusaha dan menunjukkan kemampuan yang optimal dalam pengelolaan proses pembelajaran, sehingga pembelajaran yang diberikan oleh guru dapat dengan mudah dipahami oleh siswa; 2) Kepala sekolah disarankan untuk melaksankan supervisi secara berkelanjutan, sehingga permasalahan yang dihadapi guru dalam pembelajaran maupun yang lainnya dapat diminimalkan; 3) Peneliti lain diharapkan untuk mengembangkan penelitian ini agar kendala yang dihadapi sekolah-sekolah di dunia pendidikan dapat diminimalkan. 


\section{Daftar Rujukan}

Afrianto, Irawan. 2011. Collaborative Learning System Sebuah Alternatif Konten C-Generation dan Flagship Detiknas. Majalah Ilmiah UNIKOM Vol.8, No. 1 Hal. 69-76. Tersedia Pada: https://jurnal.unikom.ac.id/jurnal/collaborative-learning-system.1e.

Agung, A.A Gede. 2010. Metodologi Penelitian Pendidikan. Singaraja: Fakultas Ilmu Pendidikan Universitas Ganesha.

Alfonso, Robert J., Firth. G. R. dand Neville, R. 1981,. Instructional. Supervision: A Behavior System. Allyn and Bacon Inc.

Depdiknas. 2008. Peraturan Menteri Pendidikan Nasional RI Nomor 13 Tahun 2007 Tentang Standar Kompetensi pengawas. Jakarta: Depdiknas

Leniwati dan Yasir Arafat. 2017. Implementasi Supervisi Akademik Kepala Sekolah Untuk Meningkatkan Kinerja Guru. Jurnal Manajemen, Kepemimpinan, dan Supervisi Pendidikan Volume 2, No. 1.

Munirah. 2015. Sistem Pendidikan di Indonesia: antara keinginan dan realita. Auladuna, Vol. 2 No. 2 Hal. 233-245. Tersedia Pada: http://journal.uinalauddin.ac.id/index.php/auladuna/article/view/879.

Neagley, Ross L. dan Evans, N. Dean. 1980. Handbook for Effective Supervision of Instruction. New York: Englewood Cliffs-Prentice Hall, Inc.

Omeri, Nopan. 2015. Pentingnya Pendidikan Karakter Dalam Dunia Pendidikan. Manajer Pendidikan, Volume 9, Nomor 3, Hlm. 464-468. Tersedia Pada: https://ejournal.unib.ac.id/index.php/manajerpendidikan/article/view/1145/0.

Selvia. 2015. Implementasi Supervisi Akademik Kepala Sekolah Dalam Peningkatan Profesionalisme Guru. Jurnal Manajer Pendidikan, Volume 9, Nomor1, Maret 2015, hlm. 43-49.

Sergiovanni Thomas J. Et. Al. 1987. Educational Governmance and Administration. New Jersey Prentice Hall Inc.

Susanto, Ahmad. 2016. Manajemen Peningkatan Kinerja Guru. Jakarta: Prenadamedia Group.

Uha, Nawawi, H. Ismail. 2013. Budaya Organisasi Kepemimpinan \& Kinerja. Jakarta: Prenadamedia Group. 